\title{
The cost of overseas visitors to an inner city accident and emergency department
}

\author{
James Colville, Amanda Burgess, Chista Kermani, Robin Touquet, Jane Fothergill
}

\begin{abstract}
Objective-To estimate, in a metropolitan accident and emergency (A\&E) department, the annual cost of treating overseas visitors whose countries of origin do not have reciprocal arrangements with Britain.

Methods-The study was retrospective. A $24 \mathrm{~h}$ period $(00.01 \mathrm{~h}$ to $24.00 \mathrm{~h}$ inclusive) on consecutive days in consecutive weeks (that is, Monday in week 1, Tuesday in week 2, etc) was costed over 52 weeks (1.8.92-31.7.93 inclusive) and extrapolated to 365 days. All visitors between those dates were divided into eligible (from countries with a reciprocal agreement) or non-eligible (from countries without a reciprocal agreement). Costs were calculated for medical and nursing care, investigation and treatment, and fixed costs.
\end{abstract}

Results-The annual St Mary's Hospital A\&E budget for the study period (01/08/92 to $31 / 07 / 93$ ) was $£ 2612200$; the average medical and nursing cost per major or minor case was $£ 66.88$ and $£ 20.08$ respectively. Investigation, treatment, and fixed costs were $£ 16.31$ per patient. In total 2704 non-eligible patients (498 major and 2206 minor cases) were treated at a cost of $£ 121705$ (95\% confidence interval $£ 114234$ to $£ 129176$ ), which was $4 \cdot 7 \%$ of the total annual budget.

Conclusions-The cost of non-eligible patients to the NHS is substantial. One possible solution would be for visitors from countries which do not offer subsidised emergency treatment to British nationals to purchase health insurance compulsorily on or before entry to Britain. The revenue could be used to improve standards of care for all A\&E patients. ( $\mathcal{A}$ Accid Emerg Med 1996;13:16-17)

Accident and
Emergency
Department,
St Mary's Hospital,
Praed Street,
London W2 1NY
J Colville
A Burgess
R Touquet
J Fothergill
St Mary's Hospital
Medical School,
London W2
C Kermani
Correspondence to:
Dr Jane Fothergill,
Consultant in A\&E Medicine

Key terms: accident and emergency; budget; treatment costs; overseas visitors.

National Health Service guidelines state that all patients regardless of nationality should receive free accident and emergency ( $A \& E$ ), ophthalmic, and dental treatment in the United Kingdom. ${ }^{1}$ None would question that all patients should be treated; many question whether the British Taxpayer should foot the bill. $^{2}$

At a time when elective operations in some hospitals are postponed, and wards and entire hospitals are threatened with closure, it is appropriate to audit the cost of emergency treatment of visitors to the NHS. Reciprocal health agreements exist between the United Kingdom and 38 countries, including all 12 EEC states, entitling British citizens to a partial refund for medical treatment in state run hospitals abroad. ${ }^{3}$ None of the other countries have such arrangements, and British nationals must pay emergency and non-emergency medical or dental costs in full. Can the British taxpayer afford to treat these nationals whose governments do not have such an agreement?

\section{Methods}

A one year, retrospective study was carried out to assess the cost of medical treatment of foreign nationals to the $\mathrm{A} \& \mathrm{E}$ department of St Mary's Hospital, London.

A $24 \mathrm{~h}$ period $(00.01 \mathrm{~h}$ to $24.00 \mathrm{~h}$ inclusive $)$ on consecutive days in consecutive weeks (that is, Monday in week 1, Tuesday in week 2, etc) was costed over 52 weeks $(1.8 .92$ to 31.7 .93 inclusive) and extrapolated to 365 days. All visitors between those dates were divided into eligible (from countries with a reciprocal agreement) or non-eligible (from countries without a reciprocal agreement).

Patients who were current United Kingdom taxpayers and those claiming or awaiting refugee or student status were excluded from the study.

Costings were calculated using various measurements: medical and nursing costs, investigation and treatment costs, and fixed costs. For the purposes of the study, patients were divided into two categories of triage group: major and minor. An average medical and nursing cost per category was calculated. Over the year staff spend equal time treating major and minor patients. These costs include all subsequent $A \& E$ dressing and review clinic attendances. Costs of investigations, including $x$ rays, ultrasound, ECGs chemical pathology, haematology, and bacteriology, were obtained from annual bills. A similar method of costing was used for drugs and appliances.

An average cost per patient (regardless of category) for investigation was calculated for care within the A\&E department. All fixed costs, such as laundry, lighting, and security were again averaged per patient as above.

All figures are presented per patient episode and confidence intervals (CI) are given Ambulance, fracture clinic, and inpatient episode costs have not been addressed.

\section{Results}

The annual St Mary's A\&E budget was $£ 2612200$, of which medical and nursing costs were $£ 1708500$, and investigations, 
Cost of treating visitors, 1992-1993; means (95\% confidence intervals).

\begin{tabular}{llllrl}
\hline $\begin{array}{l}\text { Visitors' eligibility } \\
\text { for free treatment }\end{array}$ & $\begin{array}{l}\text { Number of visitor } \\
\text { episodes in sample }\end{array}$ & $\begin{array}{l}\text { Extrapolated number of } \\
\text { visitors per annum }\end{array}$ & $\begin{array}{l}\text { \% Total patient } \\
\text { episodes }\end{array}$ & $\begin{array}{l}\text { Projected annual } \\
\text { cost }(£)\end{array}$ & $\begin{array}{l}\text { \%Annual AEEE } \\
\text { budget }\end{array}$ \\
\hline Eligible & 270 & $2141(1760$ to 2522$)$ & $3 \cdot 9(3 \cdot 4$ to $4 \cdot 4)$ & 99200 & $\begin{array}{l}3 \cdot 8(3 \cdot 3 \text { to } 4 \cdot 3) \\
\text { Non-eligible }\end{array}$ \\
\hline
\end{tabular}

treatment, and fixed costs were $£ 902700$. The total number of patients seen in the department over the 52 week period was 55356 (12780 major cases and 42576 minor cases), so the average medical and nursing cost per major or minor case was $£ 66.88$ and $£ 20.08$ respectively. Investigation, treatment, and fixed costs were $£ 16.31$ per patient. In total 2704 non-eligible patients (498 major and 2206 minor cases) were treated at a cost of $£ 121705$ (95\% CI $£ 114234$ to $£ 129176$ ) which was $4 \cdot 7 \%$ of the total annual budget (table). Of all non-eligible visitors, $13.5 \%$ were admitted to St Mary's for inpatient treatment. A quarter of all non-eligible visitors were from the USA and $19 \cdot 2 \%$ from Kuwait. Overall, the percentage of non-eligible visitors from various continents was as follows: Middle East $37 \cdot 0 \%$, North America 31.3\%, Africa 10.9\%, South America $7 \cdot 5 \%$, Indian subcontinent $5 \cdot 0 \%$, Europe $4.4 \%$ and the Far East $3.9 \%$. Data were not available from this retrospective study on the proportion of visitors who carried private medical insurance, as this information is not routinely collected.

\section{Discussion}

The number of visitors in the non-eligible category may well be an underestimate because patients may not have given complete details, especially those with or awaiting student or refugee status, who constituted $9 \cdot 8 \%$ of all visitors.

A quarter of all non-eligible visitors were American and $19 \cdot 2 \%$ Kuwaiti, most of whom travel with health insurance and expect to pay. St Mary's is in the West End of central London and is therefore likely to treat a higher percentage of visitors than many other hospitals in the United Kingdom. So who could pay the bill? The options are: (1) the British taxpayer; (2) the patients or their sponsors; (3) the Government of the national; (4) health insurance companies.

The first option is the current practice; the second could lead to animosity and may put the patient's health at risk if money was not available; the third option would require detailed and complex intergovernmental cooperation; the fourth warrants further attention. Health insurance could be purchased in the country of origin or at the United Kingdom port of entry and could be compulsory.

Details of medical insurance could be collected by receptionists during registration of patients. The fee for treatment could either be paid by the patient initially and recovered by them from their insurance company subsequently, or the A\&E department could claim directly from the insurance companies, leaving treatment free at the point of access to all comers.

At St Mary's the annual saving of $£ 121700$ (minus administration costs) would be used to improve standards of care, such as by reducing waiting times in $A \& E$ for visitors as well as for resident patients.

We thank Mr Ian Robertson and Mrs Jane Wadsworth for their help and advice.

1 Manual of guidance on NHS treatment for overseas visitors. (HC (88)/4. 8,14-6,21.) London: DHSS

2 Fletcher D. Overseas visitors costing Health Service millions. The Daily Telegraph, 4 August 1993.

3 Health Advice for Travellers. Department of Health and Central Office of Information. London: HMSO 4/93 O/N 14526/A:22-39. 